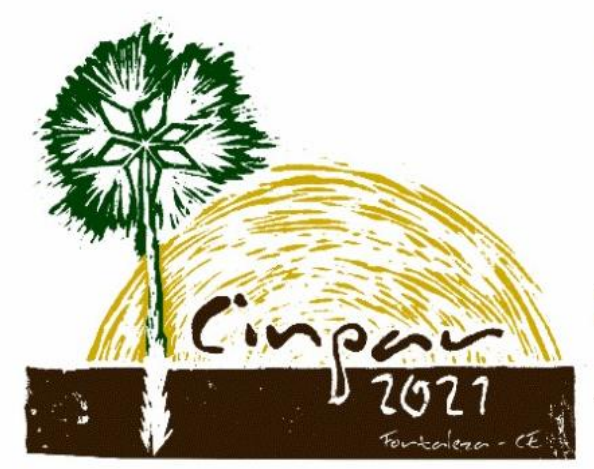

XVII Congresso Internacional sobre Patologia e Reabilitação das Construções

XVII Congreso Internacional sobre Patología y Rehabilitación de las Construcciones

XVII International Conference on Pathology and Constructions Rehabilitation

FORTALEZA (Brasil), 3 a 5 de junho de 2021

https://doi.org/10.4322/CINPAR.2021.061

\title{
A sustainable material for sustainable architecture: wood in parasite architecture
}

\author{
Sergio RINALDI ${ }^{1}$, Giorgio FRUNZIO ${ }^{1}$, Mariateresa GUADAGNUOLO ${ }^{1}$, Luciana DI GENNARO ${ }^{2}$, Luigi MASSARO ${ }^{3}$ \\ ${ }^{1}$ Department of Architecture and Industrial Design, University of Campania Luigi Vanvitelli, Aversa, Italy, \\ sergio.rinaldi@unicampania.it, giorgio.frunzio@unicampania.it,m.guadagnuolo@unicampania.it \\ 2 Department of Engineering, University of Campania Luigi Vanvitelli, Aversa, Italy, luciana.digennaro@unicampania.it \\ ${ }^{3}$ M. \& P. s.a.s., Casal di Principe, Italy, ing.luigi.massaro@gmail.com
}

\begin{abstract}
The pandemic Covid-19 has distorted the way of living and enjoying the spaces. Unfortunately, cities are often saturated and many of the public buildings fail to meet the new needs. The need to expand the spaces is a problem and an opportunity: intervening on the existing patrimony, however, requires a multidisciplinary commitment. The interventions on the built heritage have several problems, on the one hand technological, aimed at improving the energy impact of the new building, and on the other properly structural, because the existing heritage was not always built with seismic requirements.

This article presents some possible solutions for intervention on the existing patrimony for the implementation of the spaces through volumetric addition, "parasitic architecture", and how the use of wood and its derivatives can allow it.
\end{abstract}

Keywords: Parasite architecture, Sustainable architecture, Structural Analysis, CLT, Pres-Lam

\section{Introduction}

In this pandemic period, the use of space is changed. The need to expand the spaces becomes an opportunity even if the interventions on existing buildings involve two major problems: technological (Arena et al., 2017) aimed at improving the energy impact of the "new" building, and urbanistical, aimed at respecting urban planning regulations and structural, which requires the achievement of an adequate seismic safety index according to current regulations (NTC 2018).

There is static implications in terms of increased load and require, through understanding the state of fact, appropriate checks to design both local interventions on the existing building. Such interventions can concern both R / C buildings and masonry heritage (Monaco et al., 2020). For the latter, however, it is better to intervene with local reinforcements (Monaco et al., 2018). In order to preserve green space, the only way to expand spaces by reducing land consumption is to "build on the built". There are three types of intervention:

- Rooftop architecture, an elevation that uses roofs as new soils for localized expansion interventions or real complex urban systems of functions and equipment (Khalfi, 2019) (Figure 1a).

- Parasitical Architecture. In this typology, new inhabitable volumes are grafted onto existing buildings. The new parasitical volume is distinct from the host building both formally and spatially, but linked to it by a state of necessity (Figure 1b).

- Exoskeleton systems, independent volumetric expansion to be superimposed on the facades, defined by a structure on autonomous foundations. It can accommodate new spaces and support possible elevations (Di Giulio, 2010; Bellini, 2018). 

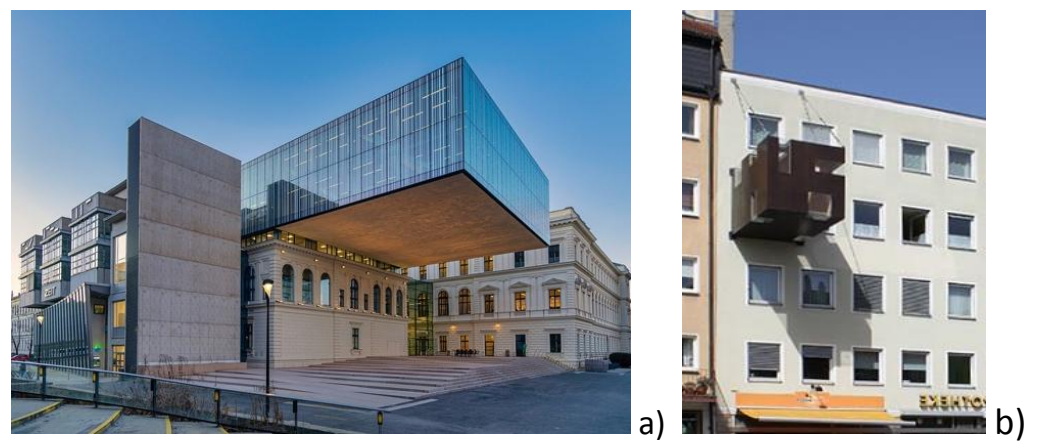

Figure 1 - Enlargement of the University of Graz, Atelier Thomas Pucher 2019 (a); Rucksack House arch. Stefan Eberstadt 2004 (b)

This article shows an overview of these types of intervention that can represent an interesting opportunity to study all the aspects that affect the building on the built. In particular, functional and structural aspects depend on the choice of materials. (Bergamasco et al., 2018; Violano et al., 2020). For example, the construction of new volumes in wood or with products derived from wood allows both the respect of high structural and architectural standards, and the increase of energy efficiency and environmental sustainability. A brief overview of the materials and technologies will be presented which, in the authors' opinion, go well with the types of intervention identified.

\section{Parasite Architecture Technologies}

In the context of wide strategies of urban regeneration, these interventions can produce virtuous effects of energy efficiency, creation of new living spaces, social services, and common areas without further land consumption.

Four layouts, three of which involve the building envelope, while the fourth is located inside open spaces delimited by building curtains, are considered (Figure 2).

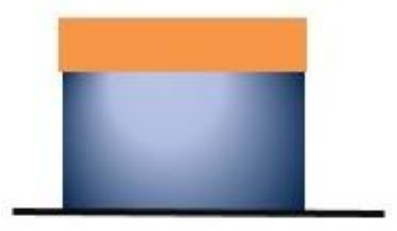

(1)

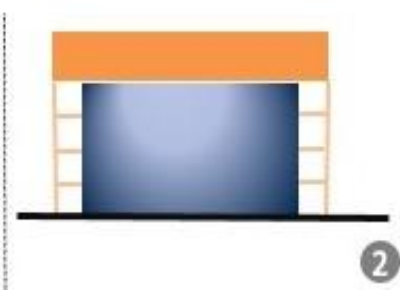

Figure 2 - Types of parasitic volums

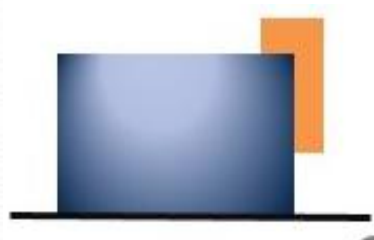

3

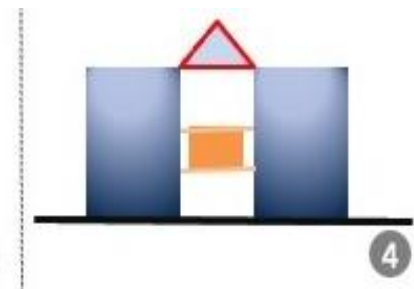

Type 1 is a new volume built at the roof level and carried by the existing structures. It replicates the typology and technologies of the underlying building reproducing its configuration without variations or differ from it in terms of shape and materials.

Type 2 is an independent structure from the existing one. It is autonomous, founded and detached from the pre-existing envelope (exoskeleton) (Figure 3).
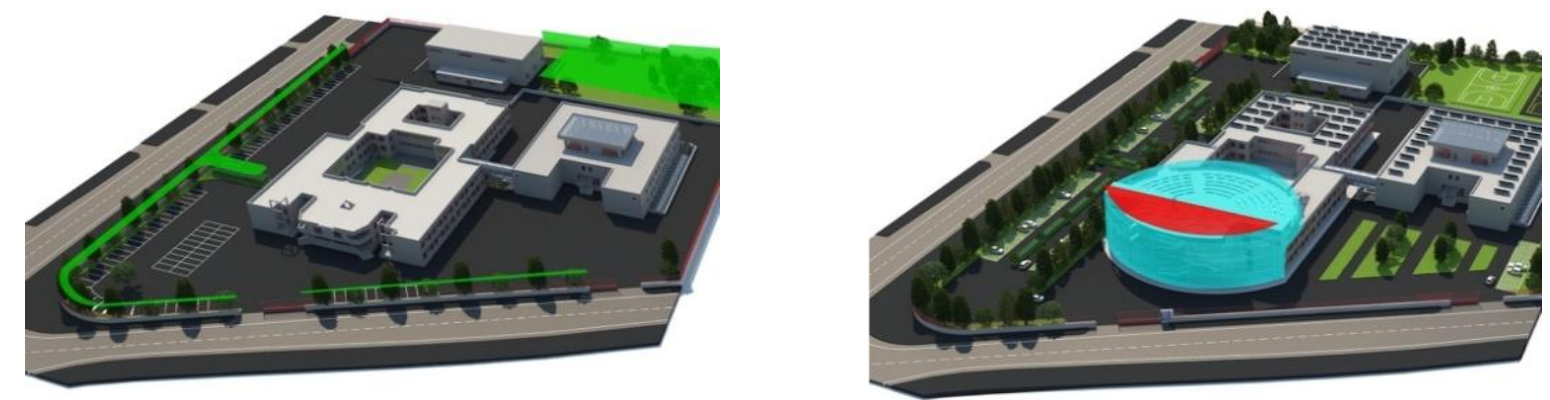

Figure 3 - Addition with exoskeleton for A. Volta Institute of Aversa (CE) Italy. (Fabozzi, 2016) 
Type 3 is a parasitic volumetric additions attached to perimeter walls and/or roofs of existing building (Figure 4). The new volumes can be expansions of housing units or constitute independent units to serve with new vertical connections.
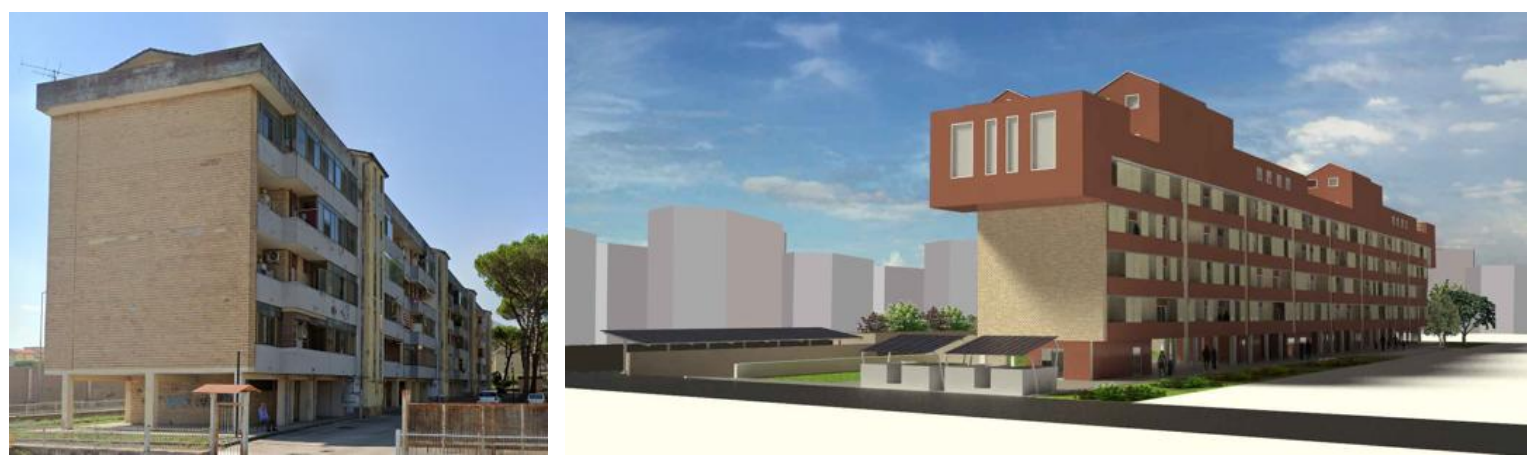

Figure 4 - Parasitic volumetric additions in the district "le fornaci" in S. Maria Capua Vetere (CE) Italy. (Borriello, 2015)

The type 4, without occupying free surface usable for outdoor activities, partially fill the courts. The new "aerial" volumes ensure the original aero-illuminating ratios. It can be appropriate for school buildings with large courtyards to maintain the function of spaces for sports and educational activities for large groups.

The load-bearing structures of the new volumes should be large span beams connected to the courtyard perimeter walls and the horizontal connections are represented by the structural walkway.

The benefits of volumetric additions should be verified in the light of some aspects, like:

- problems related to the interface between the new volumes and the existing;

- assessment of the actual technical and functional improvement of the building (accessibility, energy efficiency, safety, new services, etc.);

- structural problems due to the addition of new loads the load-bearing structure and on the foundation systems of the existing building;

- the "weight" of the new volumes on the balances (architectural, environmental, social) of the urban context.

Some of these types, for example 3 and 4, are of more complex application as regards masonry buildings, as better illustrated in the following paragraph.

\section{Parasite Architecture: Structural Aspects}

The complete knowledge of the original building is not simply expressed in a series of investigations aimed at determining the mechanical parameters that govern the structure, especially for masonry buildings (Frunzio et al., 2019). The knowledge allows finding information also and above all on the technologies, the structural schemes, and design choices made previously. The type of interactions between new and old represents a milestone for any volumetric addition. In other words, depending on the type of addendum, it is possible to understand which of the above types it falls into. The new structures can have relationships of connection or independence from the original ones.

Types 1 and 3 described in paragraph 2) are a clear example of a parasitic relationship of dependence of the "host" structure. Therefore their construction is subject to the global verification of the new configuration of the building (NTC, 2018). This mainly derives from an evident increase in the loads on the original system. Even if this does not necessarily involve in type 1 a modification of the static schemes except in terms of an increase in the load-bearing sections, in type 3 where the added mass is eccentric, a modification of the static schemes is reasonable. In both cases, the increase in masses, the displacement of the center of gravity of the stiffnesses and the modification of the shape ratios determine a modification of the seismic behavior of the system in the post-operative configuration. In the latter case, in-depth assessments of the torsional behavior of the building as a whole are required (De Stefano et al., 2014; Faella et al., 2010). 
Figure 5 shows an example of an isolated parasitic volumetric addition. This volume is prefabricated and anchored by bolts and tie rods to the reinforced concrete base structure. If, on the other hand, it is a masonry structure, the base structure must be reinforced at the attachment points (Calderoni et al., 2016; Guadagnuolo et al., 2020). In all cases, the anchors have to be made of local verifications. These elements can be added on the two facades of a linear building or the facades of an internal courtyard, as shown in Figure $5 b$.
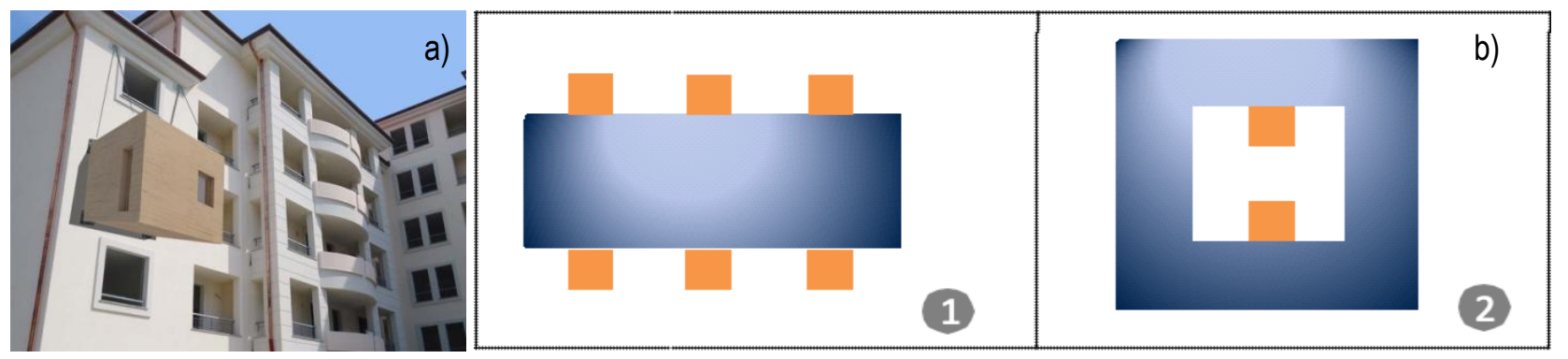

Figure 5 - Parasitic volumetric additions of type 3: a) render; b) possible layout in plan (1) linear building, (2) courtyard building

Type 2 is different because the relationship between new and old can determine both a condition of independence and a profound structural interaction. In the second hypothesis, the structural problems are the same of type 1 and type 3 . The main difference is that the parasitic structure does not completely depend on the original one. Thanks to the presence of elements that insist on the ground, partly contributes to supporting the loads weighing on the building. This condition could therefore allow entrusting to the new structure also the reinforcement function of the existing building by acting as an active element in the structural retrofit strategy (Marini et al., 2017). An example of this configuration is represented by the adaptive exoskeleton system (Bellini, 2018) as a device that intervenes on the original structural element, improving its initial characteristics.
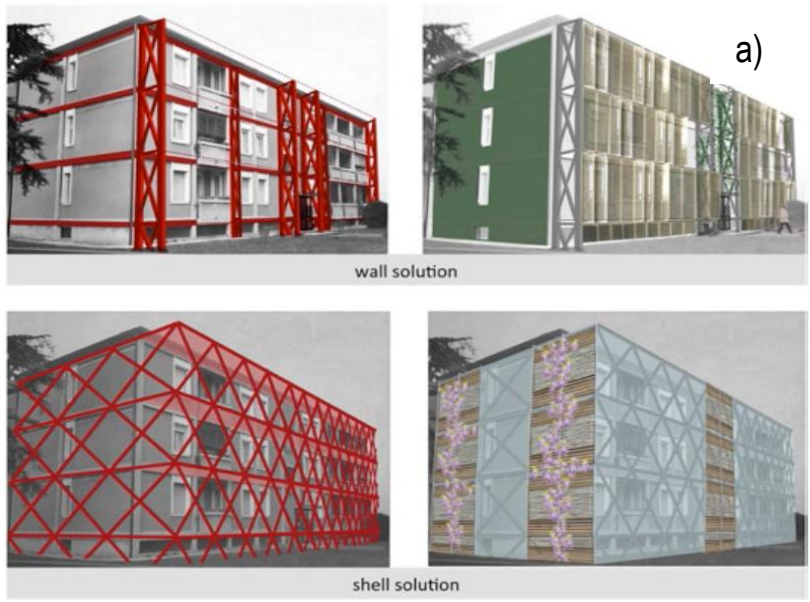
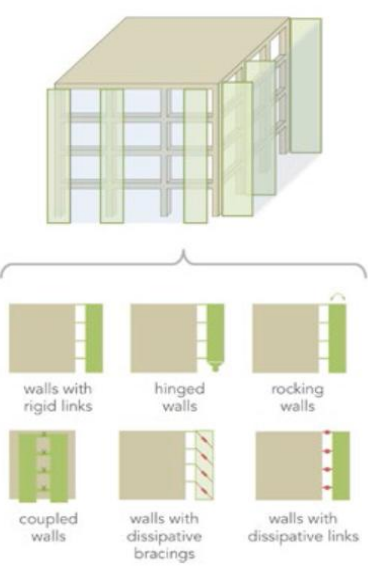
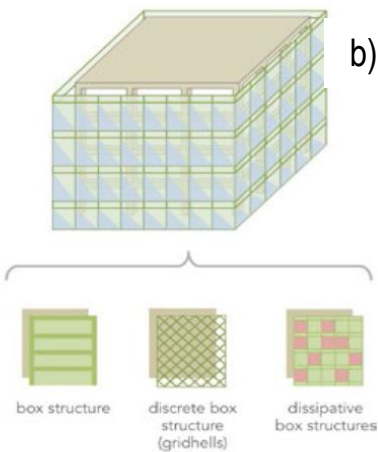

Figure 6 - a) Two retrofit solutions with adaptive exoskeleton; b) two retrofit solutions with added seismic-resistant elements (Marini et al., 2017) (Bellini, 2018)

In the case of an addendum completely independent from the original building, the real difficulty lies in preserving the condition of structural independence unchanged over time, starting first from an adequate step between the foundations of the two structures. It is necessary to avoid that the structures touch each other in the event of an earthquake and consequently design the seismic joints. (Frettoloso et al., 2015). The real difficulty is the construction of suitable structures to climb over the original building. The lights could be enormous and therefore the choice of materials and technologies for the construction of the new structure must be such as to guarantee compliance with the required requirements, but also their maintenance over time. Similarly, for large decks, floors need to be stiffened. The plan position of the 
concentric bracing must be chosen in such a way as to give the structure adequate qualities of translating bi-directional stiffness and resistance as well as torsional stiffness qualities (Alecci et al. 2019).

The presence of pillars that weigh on the beams of the over structures involves a "floating column" behavior. That determines the need for in-depth analysis that considers the punching problem, the effects of the vertical component of the seismic action, and the torsional effects additional.

An example of an independent structure from the original one is represented by the Villa Fiorita Clinic located in Aversa (Frunzio et al., 2011). The new structure completely incorporates the original building but does not interact with it and override the existing one, covering the pre-existing court. The structural scheme is of an earthquake-resistant structure with concentric bracing with active diagonals to which the dissipative function is entrusted. The interactions between the buildings is reduced by dissipation devices which as well as ensuring an adequate seismic capacity allows to limit the movements of the addendum.
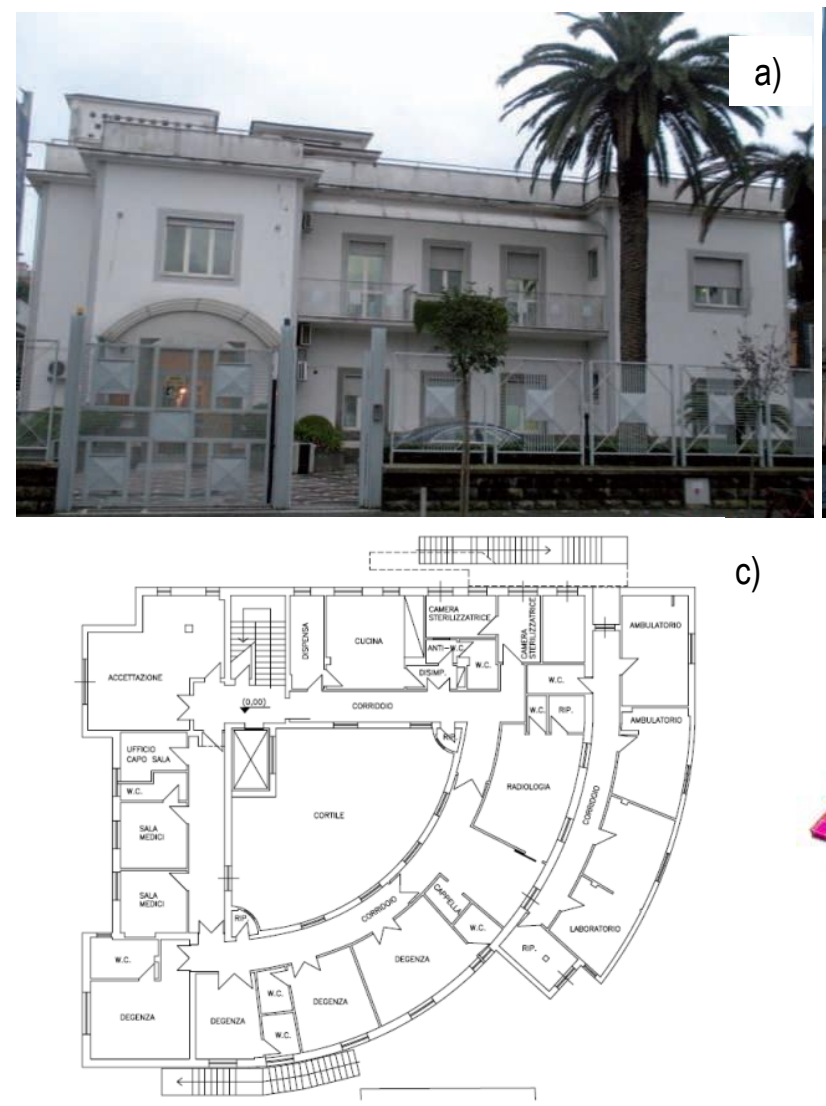

c)

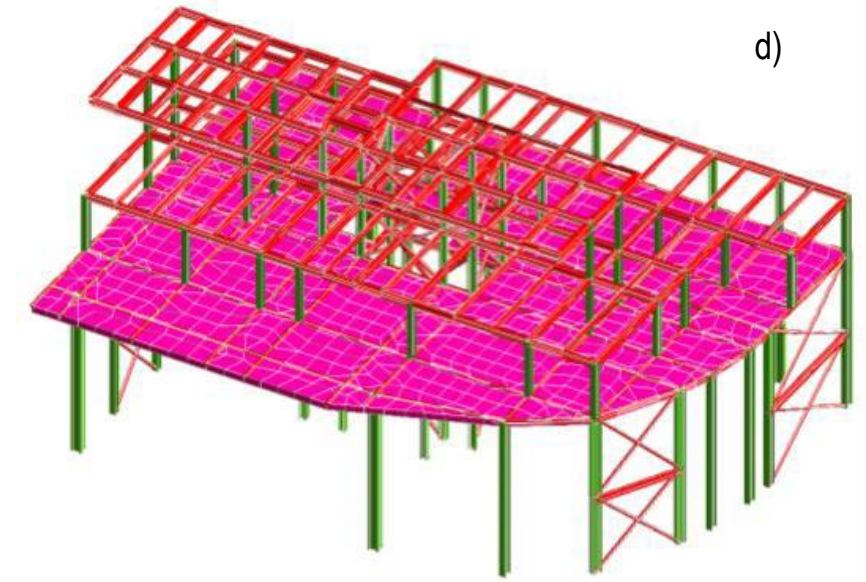

) b)

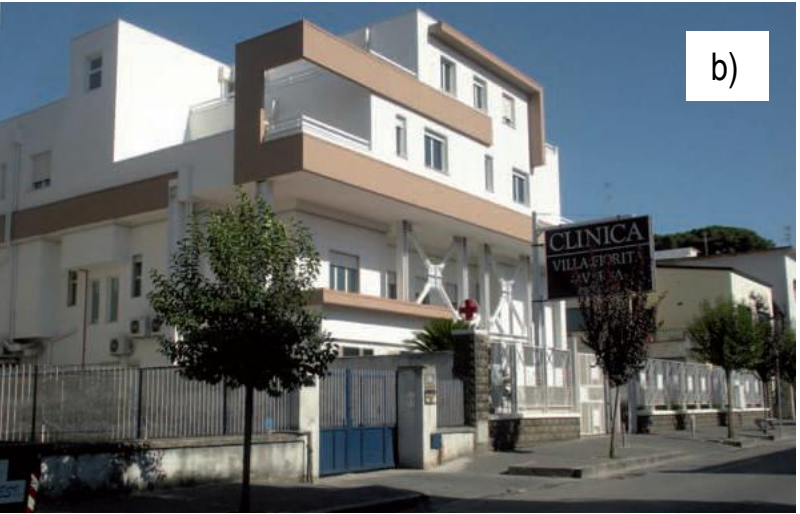

Figure 7 - Villa Fiorita Clinic: a) ante-operam; b) post-operam; c) original plan view; d) structural model of the added structure (Frunzio et al., 2011)

The last type, n. 4, except for the establishment of new connections, presents all the criticalities of the added structures. It's important to pay attention to the horizontal actions caused directly by the structural elements, orthogonal to the courtyard walls, and to the connections.

Ultimately, for type 2 and 4 , the added structures can increase the structural performance and seismic capacity of the building. This idea, linked with "low-damage" strategies, can represent the guide for a multidisciplinary and resilient project. So the dissipative elements and systems, let obtain the increasing of the seismic capacity and limit post-event damage, significantly reducing post-event repair costs. (Buonocore et al., 2014).

Today, wood and the modern materials derived from it can represent an optimal choice for interventions of volumetric additions (Margani et al., 2020; Valluzzi et al., 2021). Modern research and technological innovations have allowed overcoming the problems related to the anisotropy of the original material by creating a "new generation" of products and technologies that fully compete with the most commonly used materials (Di Gennaro et al., 2019; Frunzio et al., 2021; Izzi et al., 2018; Sun et al., 2020). So, volumetric 
additions without soil consumption joined with the use of wood create smart and sustainable buildings, which are able to adapt to events and changes of urbanized areas.

This is, also, possible thanks to the use of the Pres-Lam System (Palermo et al., 2005) which was created in response to the growing demand for seismic-resilient and sustainable structures (Granello et al., 2020). The innovation lies in applying the concept of prestressing to prefabricated wooden elements such as glulam and CLT (cross-laminated timber). This happens by creating a post-tensioning system on-site through the use of sliding cables and tensioning equipment.

Several studies have been conducted to analyze the recentering and dissipative characteristics of structures made with this technology (Akbas et al., 2017; Ganey et al., 2017; Hashemi et al., 2020). As well as the dissipative effects due to the insertion of rocking elements inside existing structures to be entrusted with the migration of damage (Pilon et al., 2019; Sandoli et al., 2020; 2021), or due to the presence of metal connections for reinforcement interventions in its plane with CLT panels (Longarini et al., 2018) or off-plan (Riccadonna et al., 2019). In general, numerous research groups are investigating the effects of reinforcement systems based on the use of panels for exoskeletons or endoskeletons on existing masonry buildings (Salgado et al., 2021; Sustersic et al., 2014).

In the end wood, in its modern configurations, fits with the different needs of building, in particular where there are requirements of high efficiency, low impact and particular construction phases.

The prefabrication makes the proposed solution also advantageous in terms of optimization. The faster installation and the use of elements substantially executed off-site allow to precisely establish the times and areas involved in the construction and assembly phases. That could ensure the continuation of the activities in the original building if necessary. Ultimately these characteristics define a low $\mathrm{CO}_{2}$ footprint not so much for the material itself as for the entire construction process.

\section{Conclusions}

"Parasitic architecture" let the realization of volumetric addition without consumption of free soil. Also, the almost totally "off-site" technologies is the most suitable for its realization. In this sense, it seems appropriate to use laminated wood components assembled with innovative technologies (Presslam and CLT). These interventions combined with the use of wood can be fully integrated into the perspective of "resilient thinking" in order to create smart buildings.

Moreover, the use of prefabricated components ensures the speed of interventions, even in urban site conditions with not always easy access. The need to expand the spaces becomes an opportunity to intervene on the existing heritage by improving the energy impact and structural performance, with a great multidisciplinary commitment. In fact, the solutions identified are of two types, added independent of the base building, with the advantage of a lower regulatory burden, or additions that become one with the base building and improve its seismic characteristics.

\section{References}

Akbas, T., Sause, R., Ricles, J. M., Ganey, R., Berman, J., Loftus, S., Dolan, J. D., Pei, S., Van De Lindt, J. W., Blomgren, H.-E. (2017). Analytical and Experimental Lateral-Load Response of Self-Centering Posttensioned CLT Walls. Journal of Structural Engineering (United States), 143(6). https://doi.org/10.1061/(ASCE)ST.1943-541X.0001733.

Alecci, V.; De Stefano, M.; Galassi, S.; Lapi, M.; Orlando, M. (2019). Evaluation of the American Approach for Detecting Plan Irregularity. Adv Civ Eng, pp.1-10. https://doi.org/10.1155/2019/2861093.

Arena, M., Cannaviello, M., Rinaldi, S., Violano, A. (2017). Retrofit Vs Rehabilitation: improving technological quality of the existing school building. World heritage and disaster. Knowledge, Culture and Representation, La Scuola di Pitagora, Napoli. ISBN 978-88-6542-582-4.

Bellini, O. E. (2018). Adaptive exoskeleton systems: remodelage for social housing on piazzale visconti (BG). In Research for Development. https://doi.org/10.1007/978-3-030-33256-3_34. 
Bergamasco, I., Gesualdo, A., lannuzzo, A., Monaco, M., 2018. An integrated approach to the conservation of the roofing structures in the Pompeian domus, Journal of Cultural Heritage, 31, 141-151.

Borriello, G. E. (2015). Addizioni volumetriche parassite nel quartiere "le fornaci" a S. Maria Capua Vetere (CE) Italia. Università degli studi della Campania luigi Vanvitelli.

Buonocore, G., Gesualdo, A., Monaco, M., Savino, M.T. (2014) Improvement of Seismic Performance of Unreinforced Masonry Buildings using Steel Frames, in: Civil-Comp Proceedings: 106, B.H.V. Topping and P. Iványi eds., Civil Comp Press, Kippen, Stirlingshire, U.K., ISBN 978-1-905088-61-4.

Calderoni, B., Prota, A., Cordasco, E.A., Sandoli, A. (2016). Seismic vulnerability of "ancient" masonry buildings and strengthening intervention strategies. Proceedings of the 16th International Brick and Block Masonry Conference, Padova, Italy, CRC Press, Taylor \& Francis Group.

De Stefano, M.; Mariani, V. (2014). Pushover analysis for plan irregular building structures. In Perspectives on European Earthquake Engineering and Seismology Ansal, A. (eds.). Springer International Publishing, Cham 34, pp.429-448.

Di Gennaro, L., Frunzio, G. (2019). Wood in the structural restoration of masonry buildings. In C. Gambardella (Ed.), Le Vie dei mercanti XVII International Forum - World Heritage and Legacy (pp. 934942). https://doi.org/ISBN 978-88-492-3752-8.

Di Giulio, R. (2010). Sustainable roof-top extension: a pilot project in Florence. Portugal Sb10 Sustainable Building Affordable to All Low Cost Sustainable Solutions.

Fabozzi, R. (2016). Addizione con esoscheletro per I'Istituto A. Volta di Aversa (CE) Italia. Università pergli studi della Campania Luigi Vanvitelli.

Faella, G., Giordano, A., Guadagnuolo, M. (2010). Unsymmetric-plan masonry buildings: Pushover vs nonlinear dynamic analysis. 9th US National and 10th Canadian Conference on Earthquake Engineering 2010, Including Papers from the 4th International Tsunami Symposium, 7, 5704-5713.

Frettoloso, C., Guadagnuolo, M. (2015). Seismic joints: architectural integration and structural safety XIII International Forum Le vie dei Mercanti - Heritage and Technology - Mind Knowledge Experince, Scuola Pitagora Editore, Napoli.

Frunzio, G., Di Gennaro, L., Guadagnuolo, M. (2019). Palazzo ducale in parete: Remarks on code provisions. International Journal of Masonry Research and Innovation, 4(1-2). https://doi.org/10.1504/IJMRI.2019.096826.

Frunzio, G., Di Gennaro, L., Massaro, L., D’Angelo, F. (2021). THE CLT PANELS IN STRUCTURAL RESTORATION: CHARACTERISTICS AND TECHNICAL REGULATIONS. SAHC 2020, 1-11.

Frunzio, G., Di Rosa, L., Lanzotti, C., Lampitiello, S. (2011). Tower raised without affecting. XXIII GIORNATE ITALIANE DELLA COSTRUZIONE IN ACCIAIO CTA, Napoli, Italy, pp.139-146.

Ganey, R., Berman, J., Akbas, T., Loftus, S., Daniel Dolan, J., Sause, R., Ricles, J., Pei, S., Lindt, J. V. D., Blomgren, H.-E. (2017). Experimental Investigation of Self-Centering Cross-Laminated Timber Walls. Journal of Structural Engineering (United States), 143(10). https://doi.org/10.1061/(ASCE)ST.1943541X.0001877.

Granello, G., Palermo, A., Pampanin, S., Pei, S., Van De Lindt, J. (2020). Pres-Lam Buildings: State-of-the-Art. Journal of Structural Engineering (United States), 146(6). https://doi.org/10.1061/(ASCE)ST.1943541X.0002603.

Guadagnuolo, M., Faella, G. (2020). Simplified design of masonry ring-beams reinforced by flax fibers for existing buildings retrofitting. Buildings, 10(1). https://doi.org/10.3390/buildings 10010012.

Hashemi, A., Quenneville, P. (2020). Seismic performance of timber structures using rocking walls with low damage hold-down connectors. Structures, 27, 274-284. https://doi.org/10.1016/j.istruc.2020.05.050.

Izzi, M., Casagrande, D., Bezzi, S., Pasca, D., Follesa, M., Tomasi, R. (2018). Seismic behaviour of CrossLaminated Timber structures: A state-of-the-art review. Engineering Structures, 170, 42-52. https://doi.org/https://doi.org/10.1016/j.engstruct.2018.05.060.

Khalfi, O. (2019). Rooftop architecture: a sustainable alternative for urban expansion. Temple University. 
Longarini, N., Crespi, P., Zucca, M. (2018). Dissipative cross lam roof structure for seismic restoration of historical churches. REHABEND, 221479, 1202-1209.

Margani, G., Evola, G., Tardo, C., Marino, E. M. (2020). Energy, seismic, and architectural renovation of RC framed buildings with prefabricated timber panels. Sustainability (Switzerland), 12(12), 4845. https://doi.org/10.3390/SU12124845.

Marini, A., Passoni, C., Belleri, A., Feroldi, F., Preti, M., Metelli, G., Riva, P., Giuriani, E., Plizzari, G. (2017). Combining seismic retrofit with energy refurbishment for the sustainable renovation of RC buildings: a proof of concept. European Journal of Environmental and Civil Engineering, 1-21. https://doi.org/10.1080/19648189.2017.1363665.

Monaco, M., Bergamasco, I, Betti, M. 2018. A no-tension analysis for a brick masonry vault with lunette, Journal of Mechanics of Materials and Structures, 13(5), 703-714.

Monaco, M., Iannuzzo, A., Tafuro, A., Gesualdo, A.,2020. Dynamic analysis of a Pompeian domus, Proc. EURODYN2020, EASD International Conference on Structural Dynamic, 2, 4922-4929.

NTC 2018 - Aggiornamento delle Norme tecniche perle costruzioni.

Palermo, A., Pampanin, S., Buchanan, A. H., Newcombe, M. P. (2005). Seismic design of multi-storey buildings using laminated veneer lumber (LVL). New Zealand Society for Earthquake Engineering Conference.

Pilon, D. S., Palermo, A., Sarti, F., Salenikovich, A. (2019). Benefits of multiple rocking segments for CLT and LVL Pres-Lam wall systems. Soil Dynamics and Earthquake Engineering, 117, 234-244. https://doi.org/10.1016/j.soildyn.2018.11.026.

Riccadonna, D., Giongo, I., Schiro, G., Rizzi, E., Parisi, M. A. (2019). Experimental shear testing of timbermasonry dry connections for the seismic retrofit of unreinforced masonry shear walls. Construction and Building Materials, 211, 52-72. https://doi.org/10.1016/j.conbuildmat.2019.03.145.

Salgado, R. A., Guner, S. (2021). Characterization of the out-of-plane behavior of CLT panel connections. Engineering Structures, 229. https://doi.org/10.1016/j.engstruct.2020.111596.

Sandoli, A., Calderoni, B. (2020). The rolling shear influence on the out-of-plane behavior of CLT panels: A comparative analysis. Buildings, 10(3). https://doi.org/10.3390/buildings10030042.

Sandoli A, D'Ambra C, Ceraldi C, Calderoni B, Prota A. "Sustainable Cross-Laminated Timber Structures in a Seismic Area: Overview and Future Trends". Applied Sciences, 2021; 11(5):2078. https://doi.org/10.3390/app11052078

Sandoli, A., D'Ambra, C., Ceraldi, C., Calderoni, B., Prota, A. "Role of perpendicular to grain compression properties on the seismic behavior of CLT walls". Journal of Building Engineering 34; 2021; 101889.

Sandoli, A., Calderoni, B. "The rolling shear influence on the out-of-plane behavior of CLT panels: a comparative analysis". Buildings 2020, 10(3), 42; https://doi.org/10.3390/buildings10030042.

Sun, X., He, M., Li, Z. (2020). Novel engineered wood and bamboo composites for structural applications: State-of-art of manufacturing technology and mechanical performance evaluation. Construction and Building Materials, 249. https://doi.org/10.1016/j.conbuildmat.2020.118751.

Sustersic, I., Dujic, B. (2014). Seismic shaking table testing of a reinforced concrete frame with masonry infill strengthened with cross laminated timber panels. WCTE 2014 - World Conference on Timber Engineering, Proceedings.

Valluzzi, M. R., Saler, E., Vignato, A., Salvalaggio, M., Croatto, G., Dorigatti, G., Turrini, U. (2021). Nested buildings: An innovative strategy for the integrated seismic and energy retrofit of existing masonry buildings with CLT panels. Sustainability (Switzerland), 13(3), 1-19. https://doi.org/10.3390/su13031188.

Violano, A., Bosco, A., Cannaviello, M., Franchino, R., Frettoloso, C., Muzzillo, F., Rinaldi, S. (2020). Teaching technological design: enhancing strategies and approach. Proceedings 12th International Conference on Education and New Learning Technologies, IATED Academy, pp. 8093 - 8103. ISBN 978-84-0917979-4. 